\title{
Feed Usage and Cattle Feeding Practices in Cattle Enterprises in the Eastern Anatolia Region: Case of Central County of Erzincan Province
}

\author{
Serdar ÖZSAĞLICAK ${ }^{1}, \quad$ Mete YANAR ${ }^{* 1}$
}

${ }^{1}$ Atatürk University, Agriculture Faculty, Animal Science Department, 25240, Erzurum, Turkey Serdar ÖZSAĞLICAK, ORCID No: 0000-0003-0359-1865, Mete YANAR, ORCID No: 0000-0002-5311-5675

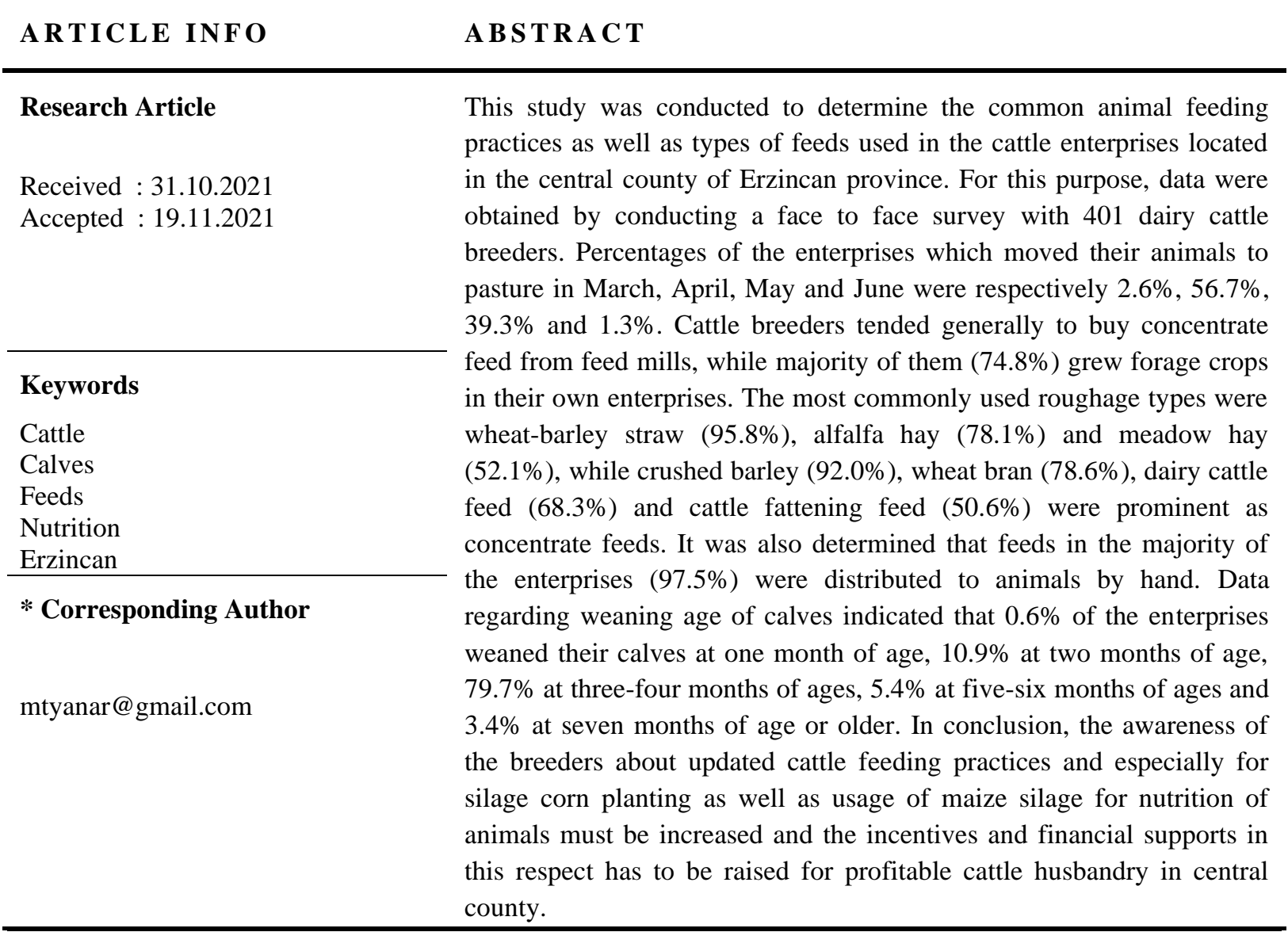

\section{Doğu Anadolu Bölgesindeki Sığırcılık İşletmelerinde Yem Kullanımı ve Sığır Besleme Uygulamaları: Erzincan İli Merkez İlçesi Örneği}

\begin{tabular}{ll}
\hline M A K A L E B İ L G I S I & Ö Z \\
\hline Araştırma Makalesi & $\begin{array}{l}\text { Bu araştırma, Erzincan ili merkez ilçede yer alan büyükbaş hayvan } \\
\text { işletmelerinde yaygın olan hayvan besleme uygulamaları ile kullanılan }\end{array}$ \\
& yem çeşitlerini belirlemek amaciyla yapılmıştır. Bu amaçla 401 süt sığırı \\
Geliş : 31.10 .2021 & yetiştiricisi ile yüz yüze anket yapılarak veriler elde edilmiştir. Mart, \\
Kabul : 19.11 .2021 & $\begin{array}{l}\text { Nisan, Mayıs ve Haziran aylarında hayvanlarını meraya çıaran } \\
\text { işletmelerin oranları sirasılyla \%2,6, \%56,7, \%39,3 ve \%1,3'tür. Sığır }\end{array}$ \\
\hline
\end{tabular}




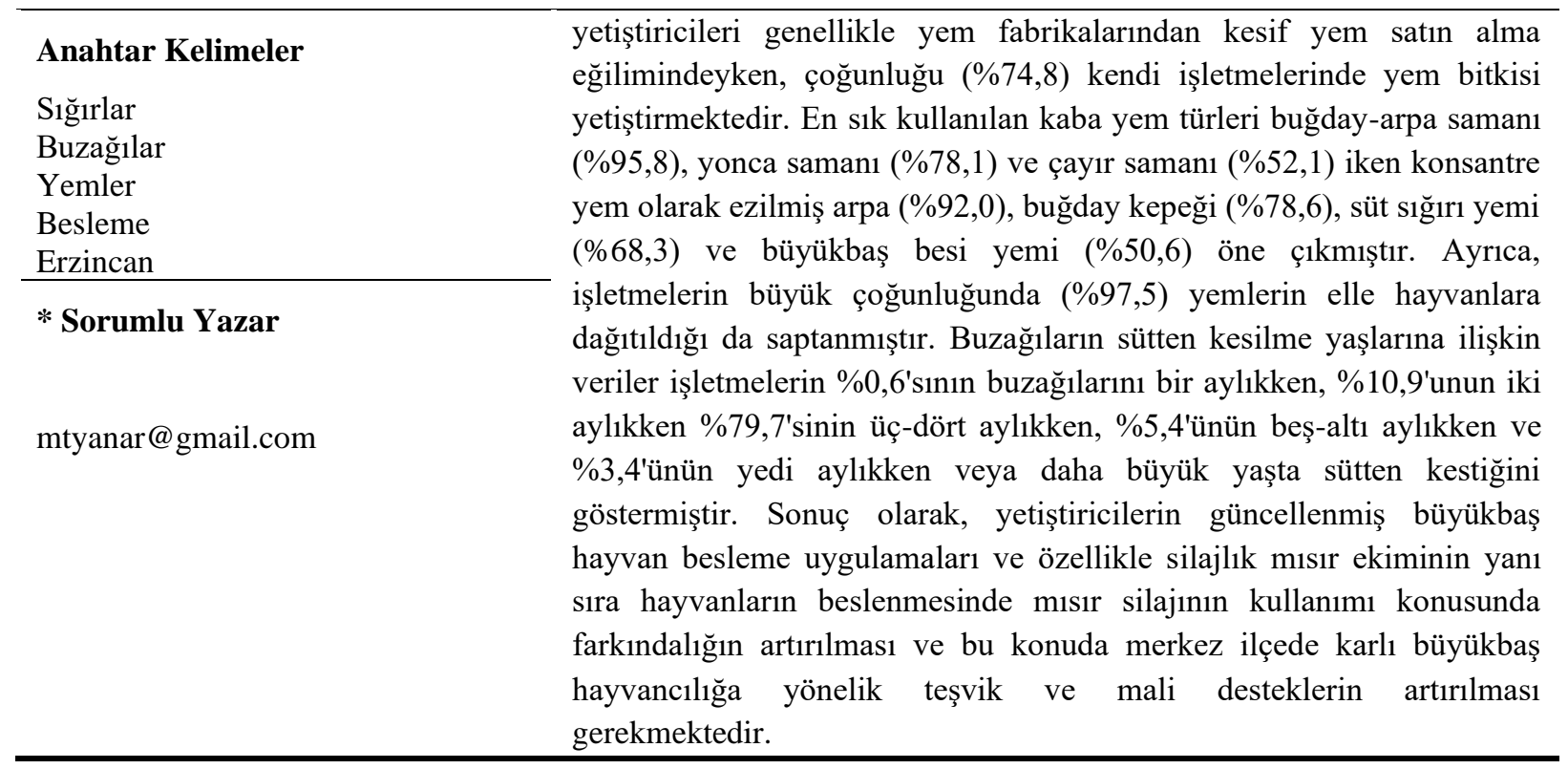

\section{Introduction}

In recent years, world population has enlarged geometrically in response to the arithmetic increasing of the food production in the World (Özgür, 2017). As a consequence of that, especially the current supplies of animal protein and energy remained inadequate to meet requirements of humans in many countries. Therefore, these circumstances has led to proteinenergy malnutrition which resulted from insufficient intake of biologically necessary nutrients (Lam, 2018).

Improving the environmental conditions of the farm animals including the use of quality roughage and concentrate feed sources is one of most important prerequisites of efficient animal husbandry. Therefore, rational nutrition in livestock enterprises must be applied in order to obtain the desired yield from animals with high genetic potential (Y1lmaz, et al. 2020). Nutrition of the farm animals influences significantly growth, performance, reproduction, immune system and products quality of the animals. Positive effects of ideal nutrition of the animals are provided by availability of nutrients in the feeds, kinds of feeding system and the level of feeding management (Kırkpınar and Açıkgöz, 2018). Although the optimum feeding of the animals was highly important for livestock production, it was indicated that farm animals in Turkey were not generally fed enough due to insufficient production of high quality forage crops besides few areas of fruitful and quality pastures and meadows by Bakır and Demirel (2001).

Feed cost is also the major part in the entire cost of animal production. Since feeds contribute to up to $60-80 \%$ of the total costs in the production of the livestock products, the economical production depends on a very large extent by efficient usage of the feeds (Igbang et al., 2021). The effectiveness of utilizing the available feed resources is especially significant for animal performance as well as increasing productivity of the livestock production.

The usage of quality forage crops for cattle feeding will lead to decreasing the use of costly concentrate feed in the cattle enterprises and increasing of their profits. Additionally, 
the high ability of cattle for utilizing cellulose-rich feed increases the significance of the cultivation of fodder crops that provides cheap and quality forages. Thus, it is crucial for cattle breeders to cultivate the required amount of roughage in their own enterprises for profitable animal farming (Güler et. al. 2016; Diler et al., 2018).

Eastern Anatolia Region has the largest share (56.80\%) in terms of meadows and pasture areas in our country. More than half of the total meadow areas and more than $1 / 3$ of the total pasture areas exist in this region. When the quantities of meadow and pasture areas in the geographical regions of Turkey are considered, the Eastern Anatolia Region takes the first place with $37.53 \%$, the Central Anatolia Region is in the second place with $31.27 \%$, and the Black Sea Region takes the third one with $10.38 \%$. In Eastern Anatolia Region, the total area of meadows along with pastures is 5485495 ha, and the total amount of dry hay produced annually in these areas is 4567510 tons. In Erzincan province, which is one of the 14 provinces of the Eastern Anatolia Region, the total area of meadows and pastures is 449433 ha and it ranks fourth in terms of total area of meadows and pastures (Okcu, 2020). The amount of the meadow and pasture areas also point out high potential of the livestock production in Erzincan province. Additionally, 3710748 heads cattle are raised in the province, and number of cattle existing in Erzincan province is 122660 heads in 2020 year (TUIK, 2021).

Up to now, any research investigating current situation, problems regarding cattle feeding as well as feeding habits and feeds used in the cattle enterprises located in central county of Erzincan province was not carried out. Therefore, this study was undertaken to determine the common animal feeding habits and practices as well as types of feeds in the cattle farms. Furthermore, results of the research will reveal the existing cattle feeding problems of the enterprises in central county of Erzincan province and they could suggest solutions for them.

\section{Material and Method}

The material of the study is obtained from 401 cattle enterprises operating in central county of Erzincan province. A face-to-face survey was conducted with owners of the enterprises which were randomly selected by simple random sampling from 2003 cattle enterprises in the central county. The cattle breeders in Briketçiler-Mezbaha-Altı location, and in 11 towns (Akyazı, Çukurkuyu, Çağlayan, Demirkent, Geçit, Kavakyolu, Mollaköy, Ulalar, Yaylabaşı, Yoğurtlu ve Yalnızbağ) as well as in 59 villages connected to the central county of Erzincan province was included into the survey.

In determining the random minimum sample size, the method used in cases where the variance is unknown, the population is limited, and there are qualitative variables related to probability, and the formula is given below (1). Here, the margin of error was $5 \%$ and the confidence level was 95\% (Arikan, 2007).

In this formula;

$$
\mathrm{n}=\left[\mathrm{N} \cdot \mathrm{t}^{2} \cdot \mathrm{p} \cdot \mathrm{q}\right] /\left[(\mathrm{N}-1) \mathrm{D}^{2}+\mathrm{t}^{2} \cdot \mathrm{p} \cdot \mathrm{q}\right]
$$

$\mathrm{n}=$ Sample Size,

N=Population Size $(\mathrm{N}=2003)$, 
$\mathrm{D}=$ Margin of Sampling Error (0.05),

$\mathrm{t}=$ Table Value $(\mathrm{t}=1,96, \alpha=0,05)$,

$\mathrm{p}=$ Population Proportion (0.5),

$q=1-p$

As a result of the calculation of the sample size, the minimum sample size was determined as about 322. The minimum number of enterprises calculated in this study was increased by 79 units and this survey was carried out with owners of the 401 cattle enterprises located in the central county of Erzincan province. The values obtained from the surveys were recorded by entering data into MS Excel program and percentage values were calculated using the information here. The effects of the educational status of the owners of the enterprises (illiterate, literate, Primary School graduate, Secondary School graduate, High School graduate and University graduate) and number of animals (1-15, 16-30, 31-45, 46-60 and more than 61 heads) raised in the enterprises on the parameters investigated in the current study was analyzed statistically by using the Chi-Square test in the SPSS package program (SPSS, 2013).

\section{Results and Discussion}

\section{The Dates of Moving Cattle to Pasture or Plateau}

As in the Eastern Anatolia Region, pasture-based animal husbandry was generally observed in Erzincan province. Results of the present study revealed that $78.0 \%$ of enterprises in the central county move their animals to pasture. Percentages of the enterprises which moved their animals to pasture in March, April, May and June were respectively 2.6\%, $56.7 \%, 39.3 \%$ and $1.3 \%$ (Figure 1). In a study carried out in Hinıs county of Erzurum province, Diler et al. (2016) reported that cattle were moved to pasture in April (25.0\%), May $(37.0 \%)$ and June (37.0\%), and the overall percentage of enterprises which utilized the pasture was $99.0 \%$. Similarly, percentages of the farmers who sent their cattle to pasture in

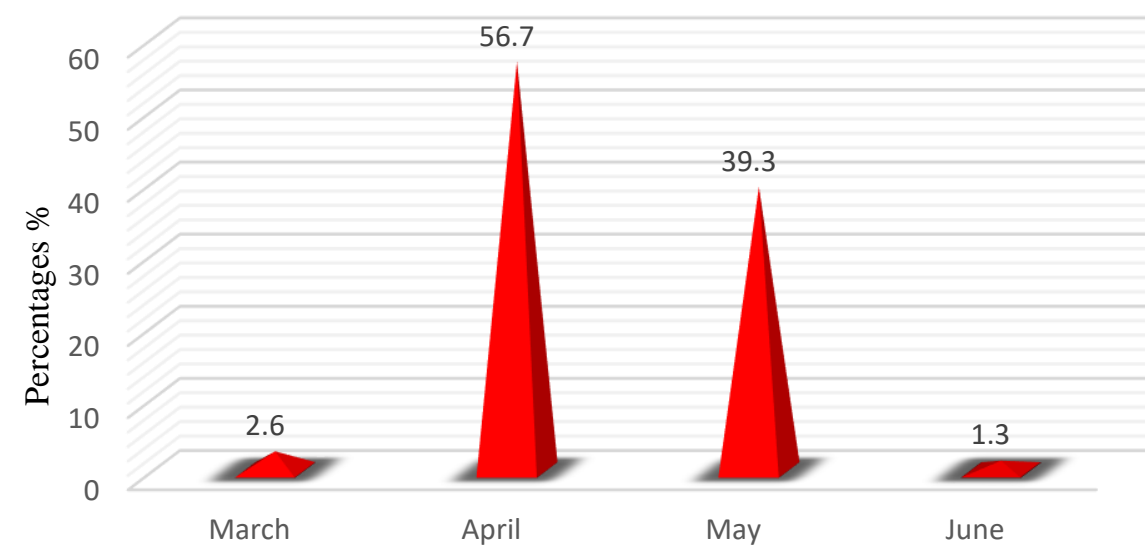

Percentages of the Months in Which the Animals are Taken to Pasture

Figure 1: Percentages of the months in which animals were taken to the pastures Şekil 1: Hayvanların meraya çıkış aylarının yüzde oranları 
Kahramanmaraş, Yakutiye county of Erzurum province and Van provinces respectively was reported as 99.0\%, 86.8\%, 76.2\% by Kaygısız and Tümer (2009), Çapadağ (2017), Şahin and Y1lmaz (2008). On the other hand, it was determined that the percentage of enterprises that moved their cattle to plateaus was $23.5 \%$, while the ratio of enterprises that did not send animals to plateaus was $76.5 \%$ in central county of Erzincan province. Percentages of the enterprises which moved their animals to plateaus in March, April, May, June and July were respectively $1.1 \%, 11.0 \%, 56.0 \%, 30.8 \%$ and $1.1 \%$ (Figure 2). On the contrary of the findings of the present study, more than half of breeders (58.0\%) in Hinis county of Erzurum province and $77.8 \%$ of those in Yakutiye county of Erzurum province moved their cattle to plateaus in June (Diler et al. 2016; Çapadağ, 2017).

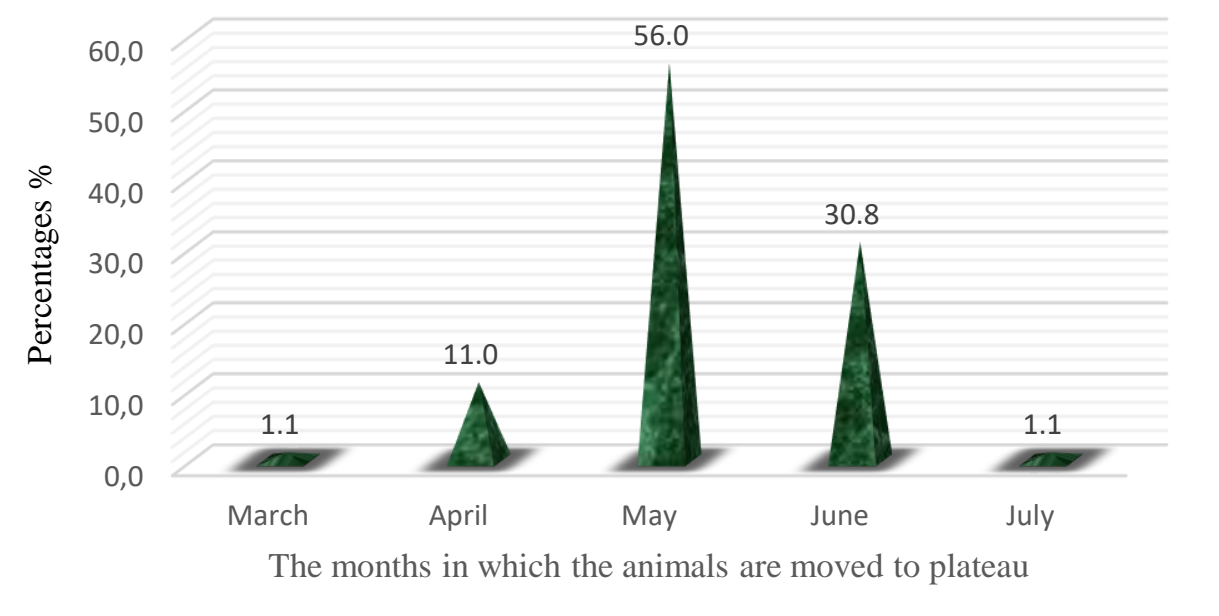

Figure 2: Percentages of the months in which animals were taken to the plateau. Şekil 2: Hayvanların yaylaya çıkış aylarının yüzde oranları

\section{Cultivation of Fodder Crops}

In the central county of Erzincan province, percentages of enterprises which used wheat-barley straw, meadow hay, dried alfalfa hay, dried sainfoin, dried vetch hay, corn silage and sugar beet pulp as roughage feeds were respectively as $95.8 \%, 52.1 \%, 78.1 \%$, $32.4 \%$, 31.2\% 29.2\%, 5.7\% (Figure 3). Likewise, roughages utilized for cattle feeding in Blacksea Region during winter season were also reported as wheat straw (50.5\%), alfalfa dried sainfoin $(11.4 \%)$, dried wetch $(6.9 \%)$, silage (7.1\%), sugar beet pulp $(3.8 \%)$, meadow hay $(9.1 \%)$, other hays (5.3\%) by Sürmen et al. (2008). Alfalfa, sainfoin, vetch, oat, rye, corn and triticale were generally cultivated in the enterprises that grow fodder crops in the central county of Erzincan province. It was also determined that alfalfa was in the first place among the most widely cultivated forage crops. Similarly, Diler et al. (2018), Bakır and Kibar (2019) and Sezer et al. (2020) reported that the highest percentage of the forage crops produced in the cattle enterprises in Narman county of Erzurum province, in Muş province and in Nevşehir province belonged to alfalfa. On the other hand, commonly produced forage crops in Tekirdag and Kırklareli provinces were noted as corn for silage and alfalfa by Öztürk et al. (2019). Diler et al. (2016) reported that $80.0 \%$ of enterprises grew sainfoin as forage crop in Hinis county of Erzurum province. However, the most commonly cultivated fodder crops in Isparta and Burdur provinces were corn (60.0\%) and alfalfa (71.4\%) respectively (Boyar and Yumak, 
2000). Likewise, Bogdanovic et al. (2012) reported that dairy cattle enterprises in Serbia used dry grass hay, dry alfalfa and corn silage as common coarse feed. Similarly, alfalfa, dry meadow hay and dried sainfoin were commonly used in the cattle enterprises in Tokat province (Ild1z, 1999), while Savran (2003) stated that $80.0 \%$ of the cattle farms in Çanakkale province cultivated oat as roughage feed.

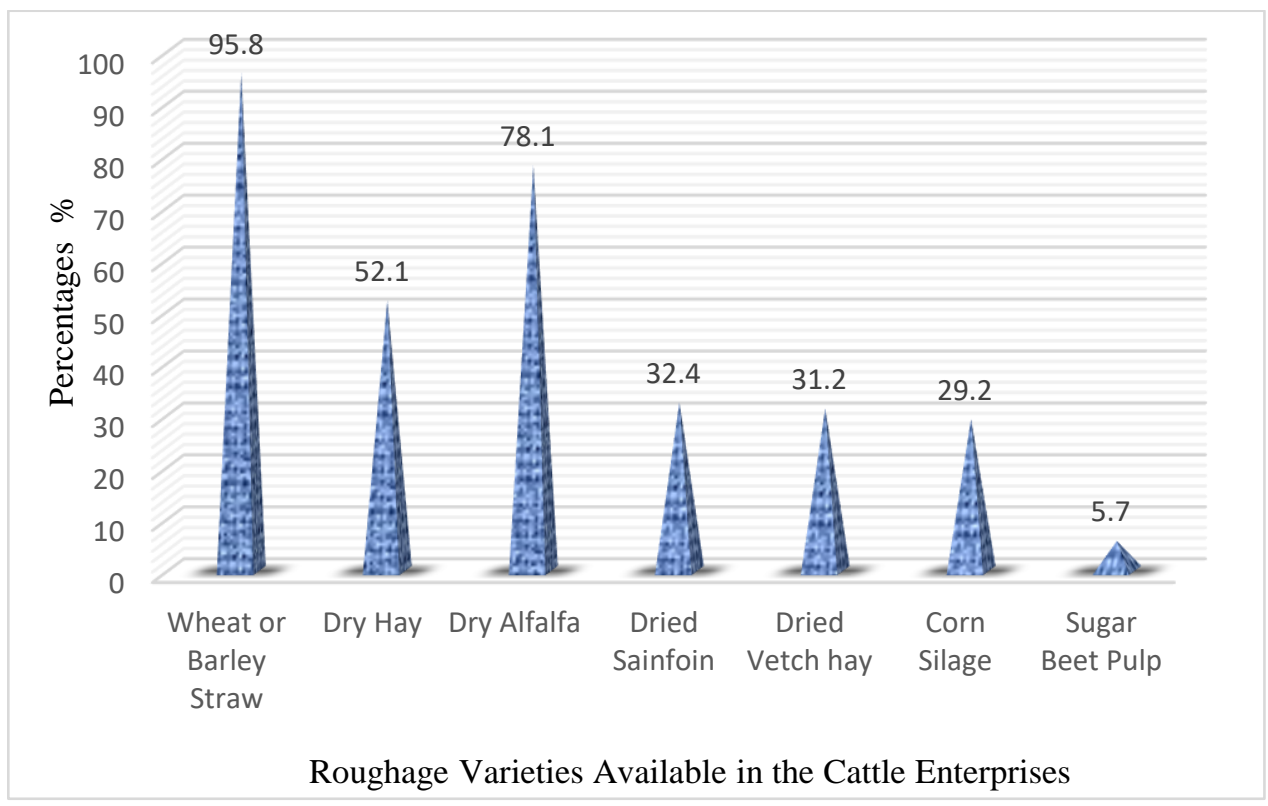

Figure 3: Percentages of roughage varieties available in the enterprises Şekil 3: Işletmelerde mevcut olan kaba yemlerin yüzde oranları

In the present study, it was found out that $38.1 \%$ of respondents utilized corn silage for feeding of their cattle, and $61.9 \%$ did not use silage. Similarly, Soyak et al. (2007) also reported that $35.7 \%$ of the cattle farms in Tekirdağ used silage for animal feeding. However, $11.7 \%$ of respondents in Kars province utilized from silage for cattle feeding (Demir et al. 2013), while $21.4 \%$ of dairy farms in Yalova used silage as course feed (Bakır and Han, 2014). Unlike these results, in a study investigating the management practices related to udder health in the early lactation period of milking cows, it was reported that grass silage containing $31.0 \%$ of dry matter was used in all of the farms (Nyman et al. 2008).

In the central county of Erzincan province, it was determined that percentage of enterprises utilizing from silage for 1-2 years was $9.4 \%, 16.8 \%$ of the respondents has been using silage for 2-4 years, $26.8 \%$ of farmers has been producing silage for 4-6 years, and $47.0 \%$ has been feeding their cattle with silage for longer than 6 years. It was also found out that silage using enterprises for more than 6 years had the highest proportion, since most of the enterprises in this county have been planting silage corn for long time. However, the results of a study conducted by Çapadağ (2017) in Yakutiye county of Erzurum province were indicated that the percentage of enterprises using silage for longer than seven years was $26.2 \%$. Additionally, the percentage of cattle enterprises fed their cattle with corn silage for five years was $23.1 \%$ as well as the proportion of farms utilized from silage for 3 years was $21.5 \%$.

According to the findings of the present study, corn silage was generally used for feeding of animals such as lactating cows (34.2\%), dried cows (8.7\%), heifers $(14.7 \%)$, old 
calves (14.5\%), young fattening bulls (16.5\%) and fattening heifers (8.7\%) (Figure 4). Furthermore, it was determined that the educational status of the owners of the enterprises and the number of animals raised in the farms had an insignificant effect on the use of silage.

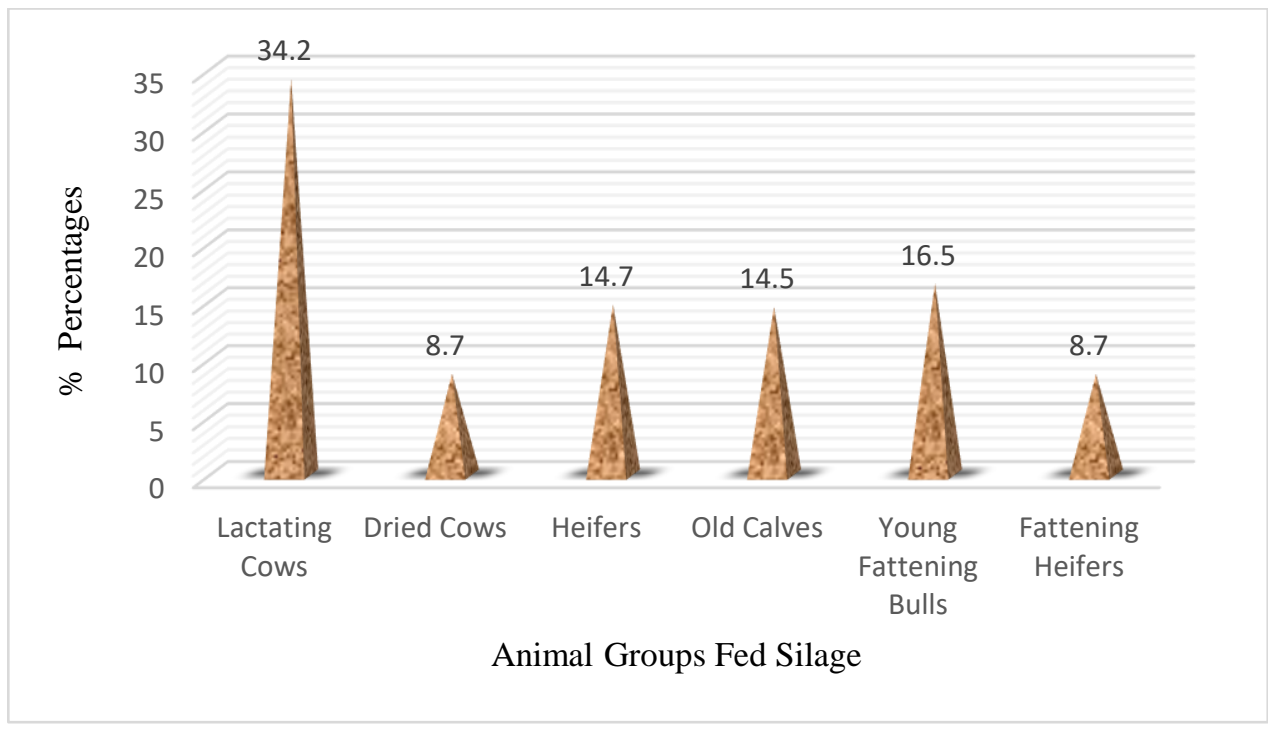

Figure 4: Percentages of silage-fed cattle type groups

Şekil 4: Silajla beslenen sı̆̆ır çeşit gruplarının yüzde oranları

\section{Sources of Roughage and Concentrate Feed Supply}

In central county of Erzincan province, $74.8 \%$ of owners of the enterprises sowed forage crops on their own farms, while $25.2 \%$ of those do not produce forage crops in their enterprises. Similarly, more than $3 / 4$ of the cattle enterprises in Antalya, Iğdır, Kars, Muş, Tekirdağ, Kirklareli provinces as well as Narman county of Erzurum province grew fodder crops, that they needed, on their own farms (Kum, 2006; Yeşil, 2015; Demir et al., 2013; Bakır and Kibar, 2019; Öztürk et al., 2019; Diler et al., 2018). On the contrary of results of the present study, findings of other studies carried out in different regions of Turkey revealed lower percentages (47.2\% in Konya 52.0 in Tekirdağ, $61.2 \%$ in Yalova, $16 \%$ in Hinıs county of Erzurum province) of enterprises which grew their own forage crops (Uzal and Uğurlu 2006; Soyak et al. 2007; Bakır and Han, 2014; Diler et al. 2016).

It was also determined that percentage of farms in the central county of Erzincan province that grew their own fodder plants was significantly $(\mathrm{P}<0.05)$ influenced by the number of animals raised in the enterprises. In other words, the number of farmers engaged in the production of fodder crops has raised along with increasing of the number of animals in their enterprises (Figure 5).

Sources of concentrate feed supply, another type of feed used in feeding of animals at the enterprises, was also investigated in this research. Results of the current study indicated that $8.1 \%$ of enterprises produced their own concentrate feeds in their farms while $81.5 \%$ of those purchased it from feed mills. In addition, $7.6 \%$ of the cattle breeders bought the concentrate feed from feed mills whenever their needs were not met by their production, and $2.8 \%$ of those provided it from Agricultural Credit Cooperatives. The result is in accordance with 


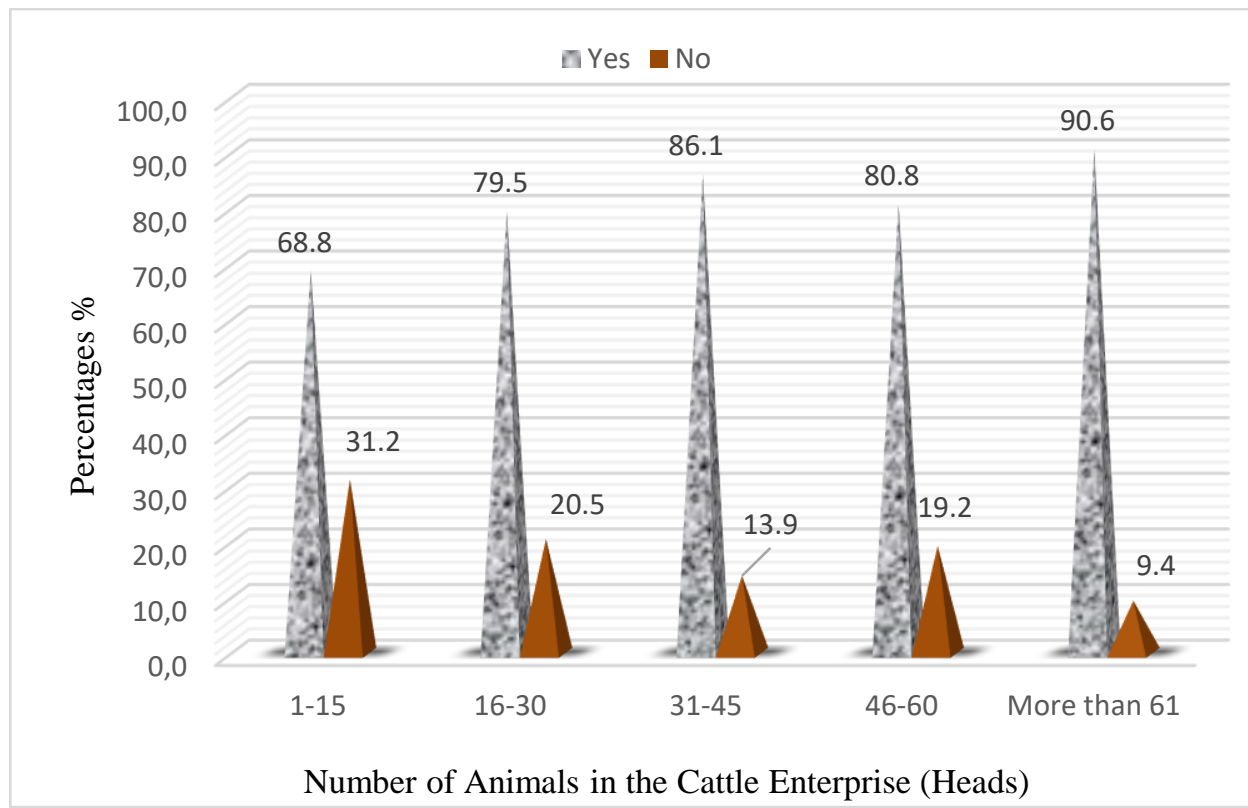

Figure 5: Percentages of enterprises that grow fodder crops according to the number of animals

Şekil 5: Hayvan sayılarına göre yem bitkileri yetiştiren işletmelerin yüzde oranları

findings of Bakır and Han (2014) who studied the structural features of dairy cattle breeding enterprises in Yalova province. They reported that $87.1 \%$ of enterprises purchased concentrate feeds from feed dealers, while $10.9 \%$ and $1.9 \%$ from unions and cooperatives as well as feed mills respectively. Similarly, results of a study conducted in Tekirdağ province revealed that $65.0 \%$ of concentrate feed was purchased from feed mills, $23.0 \%$ obtained from cooperatives, and $12.0 \%$ produced it by themselves (Soyak et al., 2007). Likewise, the majority of cattle breeders in Hinıs county of Erzurum province preferred feed factories (64\%) for the supply of concentrate feed, while the percentage of farmers who preferred Agricultural Credit Cooperatives was extremely low (2\%). Percentage of those who produced concentrate feeds in their own enterprises was also determined as $19 \%$ by Diler et. (2016). Kaygısız and Tümer (2009) and Daş et al. (2014) stated that concentrate feed is mostly acquired from outside the farm, while Dou et al. (2001), Önal and Özder (2008), Bogdanovic et al. (2012) and Tilki et al. (2013) was indicated that the majority of concentrate feed is met from within the enterprise. On the other hand, Soyak et al. (2007) and Sezer et al. (2020) found out respectively that $65 \%$ and $69.5 \%$ of breeders purchased the concentrate feeds from local feed dealers.

In the present study, It was also revealed that the effect of the number of animals available in the enterprises on the source of concentrate feed supply was not statistically significant (Figure 6). 


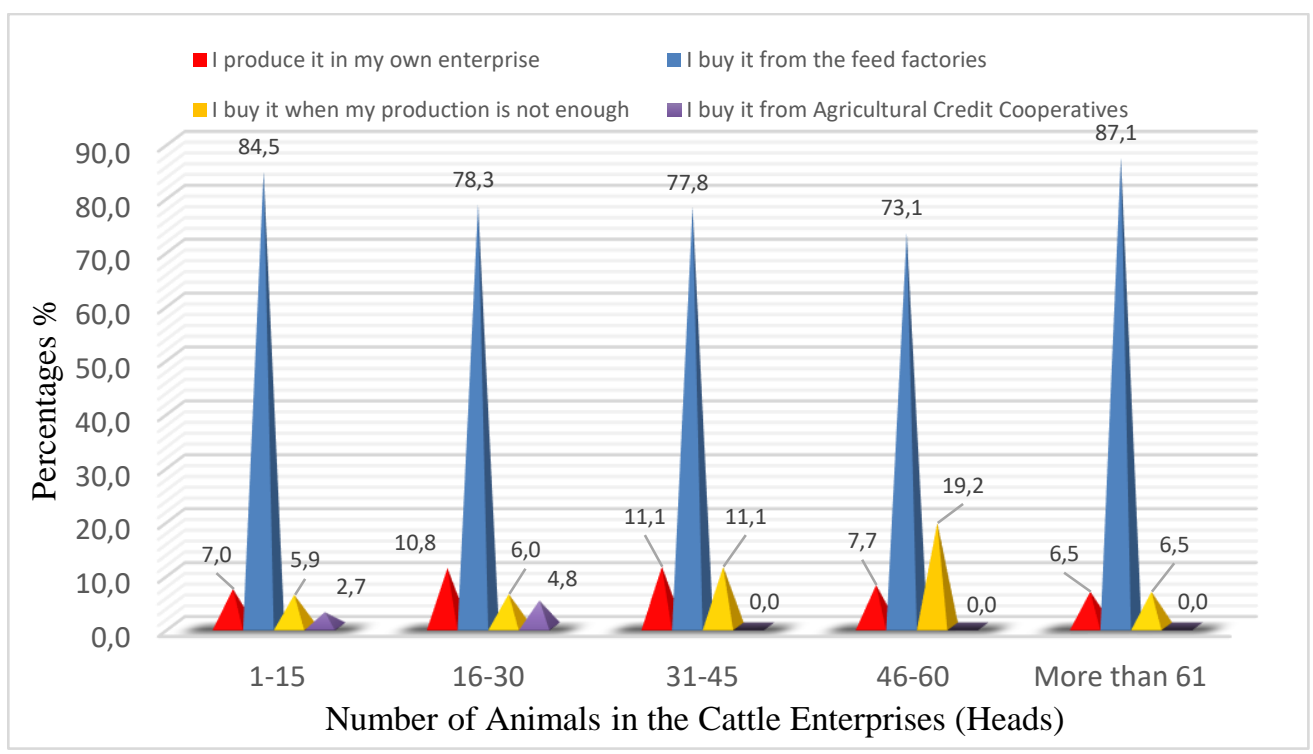

Figure 6: Distribution of sources of concentrate feed supplies according to the number of animals available in the enterprises

Şekil 6: Hayvan sayılarına göre kesif yemin sağlandı̆̆ı kaynakların işletmelere dă̆ılımı

\section{Types of Concentrate Feed Used in the Cattle Enterprises}

In the present study, it was determined that the percentages of types of concentrate feeds used in the cattle enterprises were $92.0 \%$ crushed barley, $78.6 \%$ wheat bran, $68.3 \%$ dairy cattle feed, $50.6 \%$ cattle fattening feed and $19.0 \%$ wheat (Figure 7). Commercial feeds including dairy cow feed and cattle fattening feed are the most commonly used concentrate feeds in various regions of Turkey like central county of Erzincan province. Results of studies

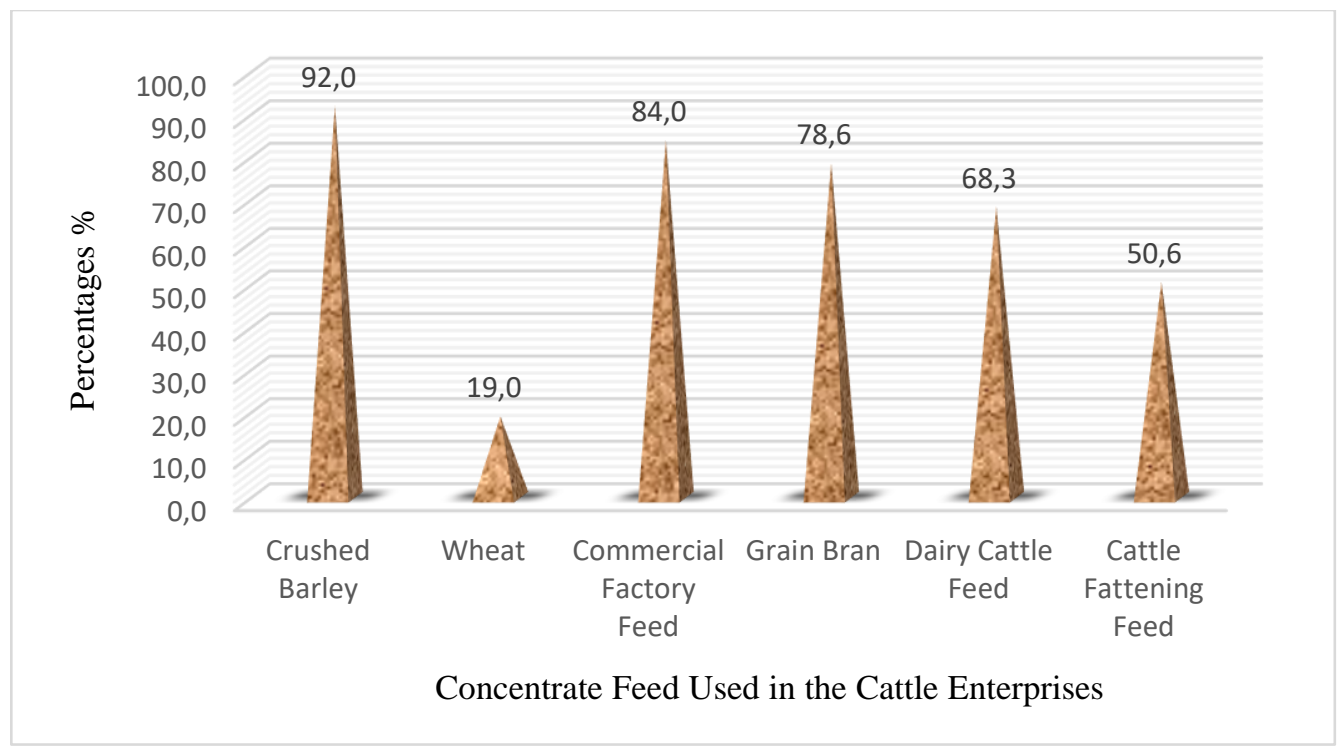

Figure 7: Percentages of the concentrate feeds used in the enterprises Şekil 7: İsletmelerde kullanılan kesif yemlerin yüzde oranları

conducted by Tugay and Bakır (2008), and Kaygısız and Tümer (2009) indicated that commercial dairy cow feed is generally used as concentrate feed in cattle farms located in the 
Giresun and Kahramanmaraş provinces. Similarly, Uçak (1992) has also point out that $63.33 \%$ of the enterprises raising imported cattle in Samsun province fed the animals with commercial factory feed. Likewise, it was determined by Diler et al. (2016) that commercial concentrate feed is used in $64 \%$ of the cattle enterprises located in Hinis county of Erzurum province, and the use of barley and wheat bran is at a very low level. However, crushed barley $(34 \%)$, cattle fattening feed $(23 \%)$ and dairy cattle feed $(22 \%)$ are kind of the concentrate feeds which were generally used as concentrate feed in the enterprises in the Narman county of Erzurum province (Diler et al., 2018).

\section{Cattle Feeding Techniques}

In the present study, it was determined that $49.1 \%$ of the farms fed the animals twice a day, $47.6 \%$ three times a day, 3.3\% more than three times a day. In addition, it was found out that first roughage and then concentrate feed was given to cattle in $5.9 \%$ of the enterprises, mixture of the roughage and concentrate feed together was offered to animals in $88.5 \%$ of the farms and first concentrate feed then roughage was given to cattle in $5.6 \%$ of the enterprises (Figure 8).

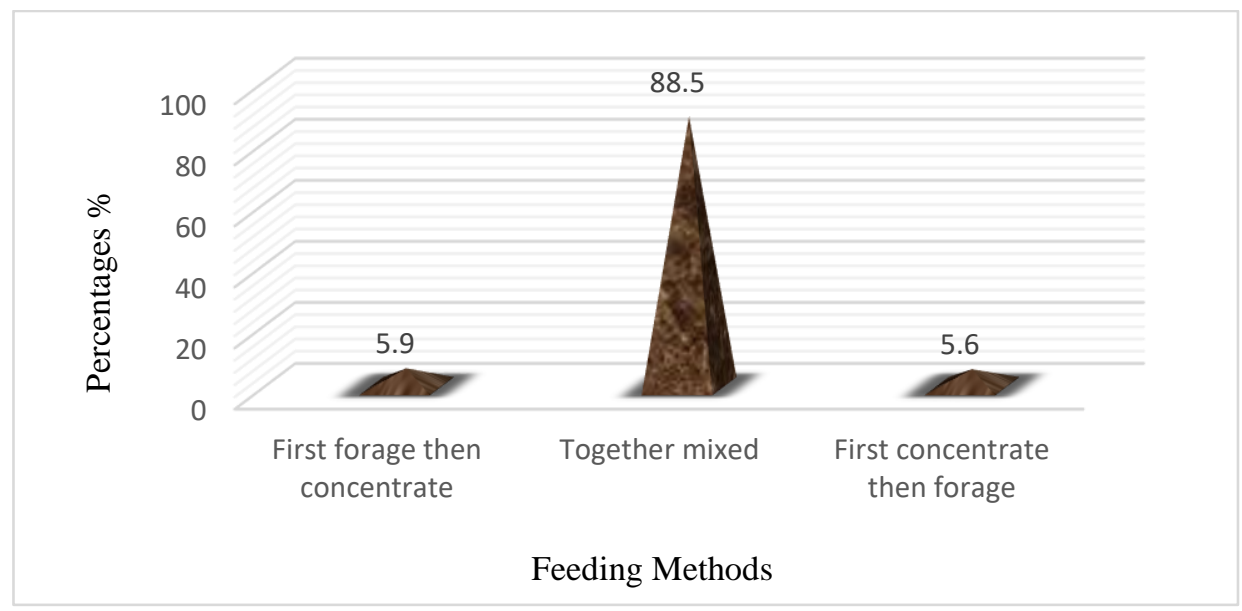

Figure 8: Percentages of the methods of feeding animals Şekil 8: Hayvanlarl yemleme yöntemlerine ait yüzde oranlar

In the studies conducted in other regions of Turkey, Önal and Özder (2008) indicated that $63.2 \%$ of the breeders fed cattle twice a day, while $31.6 \%$ fed three times. Similarly, Çapadağ (2017) stated that $70.6 \%$ and $27.7 \%$ of the surveyed enterprises fed the animals twice a day and three times a day respectively. Furthermore, first coarse and then concentrate feed in these farms was usually (47.9\%) given to the animals. In addition, it was indicated that $74.8 \%$ of enterprises in Konya feed their animals twice a day, and $70.6 \%$ of those used mixed ration for the cattle nutrition (Akkuş, 2009). Another study conducted in Ankara and Aksaray provinces reported that mixed feed was given together at two times a day in $71.0 \%$ of enterprises in Ankara, 51.4\% of enterprises in Aksaray at three times a day, and coarse feed and concentrate feed were given together at $67.7 \%$ of enterprises in Ankara, and $64.8 \%$ in Aksaray provinces (Tatar, 2007).

Feed distribution to animals was carried out manually in $97.5 \%$ of these enterprises in central county of Erzincan province while distribution of the feeds was performed with a 
tractor in $2.6 \%$ of them. As it can be seen, since the modern system has not been fully implemented in the cattle breeding enterprises in the central county and the mechanization is not at the desired level, the percentage of the manual distribution of the feeds was found to be quite high.

Likewise, Önal and Özder, (2008) reported that feed distribution was carried out manually in $98.2 \%$ of the enterprises in Edirne province, and tractor distribution was carried out in $1.8 \%$ of them. Bayraktar et al. (2010) stated that the distribution of feed in the cattle enterprises in the Ahlat and Adilcevaz counties of Bitlis province was carried out by using tractor trailers in 2 farms while feeds were distributed manually in the other 21 enterprises. It has also been determined that the effects of the number of animals in the enterprises and the educational status of the owners of the enterprises on the feed distribution method to the animals were not statistically significant.

In a vast majority of the enterprises in the central county of Erzincan province $(95.0 \%)$, cattle were fed based upon farmers' own knowledge and experience, in $4.2 \%$ of the enterprises in direction of the advices of Veterinarians. It was also determined that $1.7 \%$ of the breeders received information for cattle feeding from unions and cooperatives, and $0.7 \%$ of those followed the recommendations of the feed mills while $0.5 \%$ of those fed their cattle according to the advices of Agricultural Engineers (Animals Scientists) (Figure 9). The majority of the owners of the farms fed animals based on their own experiences in central county of Erzincan province. This result was in agreement with findings of Elmaz et al. (2010) and Çapadağ (2017) who reported that $92.6 \%$ and $86.6 \%$ of the breeders fed the

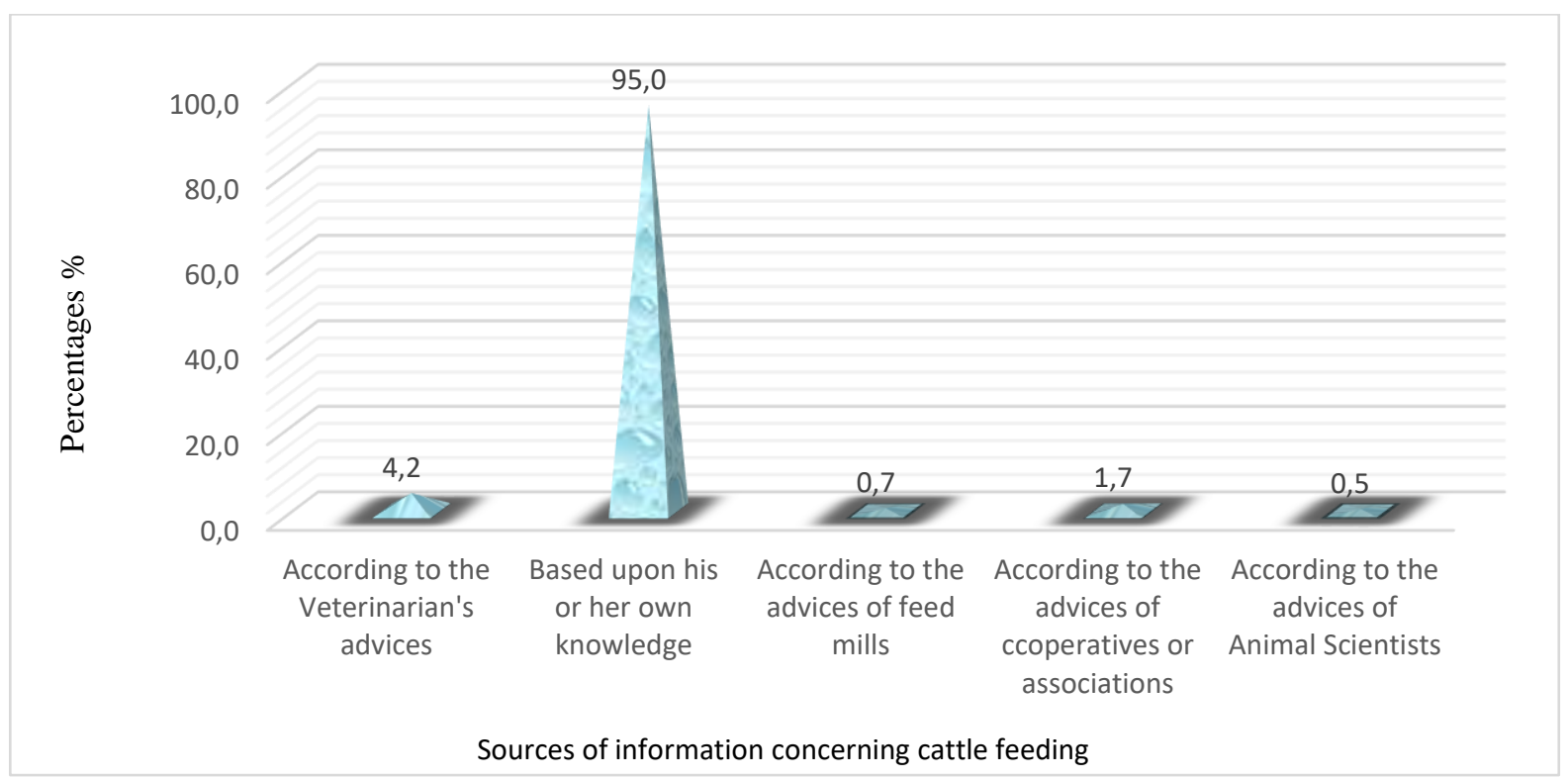

Figure 9: Percentages of sources of information concerning cattle feeding Şekil 9: Siğırların yemlenmesi ile ilgili bilgi kaynaklarının yüzde oranları

animals according to their own conventional knowledge in Burdur province and Yakutiye county of Erzurum province respectively. Similarly, it was reported by Demir et al. (2013) that $72.2 \%$ of dairy cattle farms in Kars province were fed in line with their own knowledge and experience. 


\section{Calf Feeding Practices}

The periods of starting to give roughage and calf starter (concentrate feed) to young animals after birth were also investigated in cattle enterprises in central county of Erzincan. Most of the cattle breeders $(36.1 \%)$ started to give roughage and concentrate feed 8 weeks after birth while percentages of others who initiated to feed dry feeds to calves in one, two, three, four, five, six and seven weeks of postpartum were respectively $14.9 \%, 11.3 \%, 11.0 \%$, $18.9 \%, 2.5 \%, 3.7 \%$ and $1.7 \%$. On the other hand, Tatar (2007) indicated that $24.6 \%$ of the enterprises in Ankara started to give calf concentrate feed and dry hay to calves in the first week and $26.2 \%$ in the second week, while these values in Aksaray were 28.8\% and 20.9\% respectively. Age of first time feeding concentrate and roughage to calves in Konya province was reported as 23.3 days of postpartum by Akkuş (2009) while roughage and concentrate feed were first offered to calves at average of 24.5 days old in Yakutiye county of Erzurum province (Çapadağ, 2017). The effect of the educational status of the owners of the enterprises on the periods of starting to give roughage and calf starter to young animals after birth was found statistically insignificant in the current study.

The percentages of enterprises that the first time calves were given water after birth were found to be $27.0 \%$ immediately after birth, $20.3 \%$ after one week, $11.3 \%$ after two weeks and $41.4 \%$ after three weeks. However, in $44.2 \%$ of the enterprises in Yakutiye county of Erzurum province, water was first introduced to the calves between 1 and 10 days of postpartum while $21.3 \%$ and $28.6 \%$ of these respectively were given water first time between 11 and 20 days old and following 21 days of postpartum (Çapadağ, 2017). On the other hand, Tatar (2007) stated that $61.7 \%$ of the enterprises in Ankara and $73.2 \%$ in Aksaray started to give water to the calves within the first week, and there are also enterprises in both provinces that do not give water to the calves until the age of 20 days. The effect of the educational status of the owners of the enterprises on the first time calves were given water after birth was determined not to be statistically significant in the current study.

According to evaluation concerning weaning age of calves made in the province of Erzincan, $0.6 \%$ of the enterprises weaned their calves at one month of age, $10.9 \%$ at two months of age, $79.7 \%$ at three-four months of ages, $5.4 \%$ at five-six months of ages and $3.4 \%$ at seven months or more. In other studies investigating the weaning times of calves; Kaygisiz et al. (2008) and (Yeşil, 2015) respectively reported that in 56.0\% and $61.5 \%$ of dairy cattle farms in Kahramanmaraş and Iğdır provinces calves were weaned at 3-4 months of age. Kum (2006) reported that calves in most of the farms (48.82\%) located in Antalya province were weaned at the end of the 4th month. On the other hand, milk feeding period in the farms of the Giresun region was around (47.5\%) 2 months of age (Tugay and Bak1r 2008).

In the present study, the effect of the educational status of the owners of the farms on the weaning age of calves was not statistically significant (Figure 10).

As part of this assessment of the feeding of calves that have an important place in enterprises, it was found out that $98.9 \%$ of enterprises fed the calves with colostrum after birth, and $1.1 \%$ do not give colostrum to calves. The percentages of the enterprises fed newborn calves for one day, two days, three days of postpartum with colostrum in central county of Erzincan province were determined to be $3.1 \%, 6.0 \%, 90.8 \%$ respectively. 


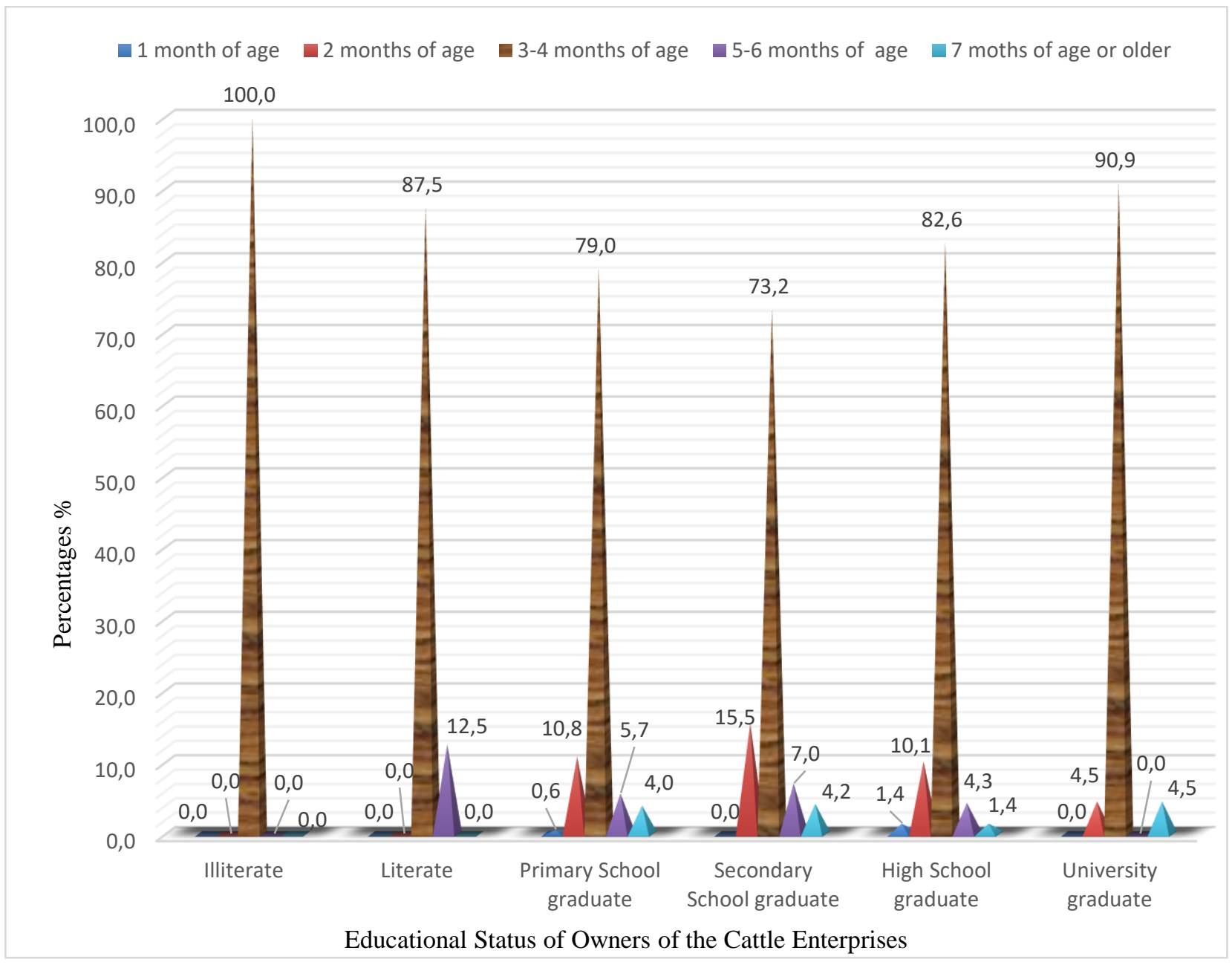

Figure 10: Distribution of weaning ages of calves according to the educational status of the owners of the enterprises.

Şekil 10: İ̧letme sahiplerinin ĕgitim durumlarına göre buzağıların sütten kesim yaşlarının işletmelere göre dă̆ılımı

Likewise, Çapadağ (2017) stated that the percentage of farms offered colostrum to calves was $91.3 \%$ while $65.7 \%$ of these enterprises gave colostrum to calves for three days after birth in the Yakutiye county of Erzurum province. Additionally, Koçyiğit et al. (2016) reported that $75.0 \%$ of the farms in Hinis county offered colostrum to the new-born calves while $68.0 \%$ of these enterprises fed the young animals with colostrum for two days. In a study conducted in Konya by Akkuş, (2009), the percentage of enterprises feeding colostrum to newborn calves was $99.5 \%$ and the percentages of enterprises feeding colostrum for the first three days in Ankara and Aksaray were 53.3\% and 80.4\% respectively (Tatar, 2007). In the present study, it was also determined that the effect of the education level of the owners of the enterprises in the central county of Erzincan on the duration of colostrum feeding after birth of the calves was found to be statistically insignificant.

\section{Conclusion and Suggestions}

In the central district of Erzincan province, pasture-based cattle breeding is dominant. Moreover, a significant part of the animals are moved to pasture in the early spring period. For this reason, pasture alone is insufficient in terms of feeding of the animals in this period. 
Despite this negative fact concerning animal feeding in the central county of Erzincan province, the production of forage crops in 3/4 of the existing enterprises was evaluated as a positive situation. There was an increase in the number of cattle enterprises which produced forage crops as the number of animals raised on farms increases. The size of the enterprise is seemed as the biggest obstacle in front of the breeders in transition to modern animal husbandry. The incentive system applied in animal husbandry should be given to enterprises with at least 30-40 cattle instead of small family enterprises, thus increasing of the size of the enterprises should be encouraged.

On the other hand, the fact that silage production is not at the desired level was considered as an important nutritional problem for dairy cattle breeding in the central county of Erzincan province. In conclusion, the awareness of the owners of the enterprises especially for silage corn planting has to be increased and the incentives and financial supports in this respect should be raised. Both of training courses and projects about animal feeding and preparation of rations for cattle including cows, heifers and calves needs to be developed in order to increase the knowledge, awareness, skills and technical education levels of the cattle breeders. At the same time, agricultural extension service delivery should be boosted more effectively in the rural areas.

\section{References}

Akkuş, Z., 2009. Konya İlindeki Süt Sığırcılığı İşletmelerinin Yapısal Özellikleri. Yüksek Lisans Tezi. Selçuk Üniversitesi, Fen Bilimleri Enstitüsü.

Arıkan, R., 2007. Araştırma Teknikleri ve Rapor Hazırlama. Asil Yayın Dağıtım Ltd. Şti. ISBN:975-8784-35-8, Ankara.

Bakır, G., Demirel, M., 2001. Van İli ve İlçelerindeki Sığırcılık İşletmelerinde Kullanılan Yem Çeşitleri ve Hayvan Besleme Alışkanlıkları. YYÜZF Tarım Bilimleri Dergisi 11(1): 29-37.

Bakır, G., Han, F., 2014. Yalova İlindeki Süt Sığırı İşletmelerinin Yapısal Özelliklerini Etkileyen Faktörler: Yem ve Besleme Alışkanlıkları. Türkiye Tarımsal Araştırmalar Dergisi 1, 55-62.

Bakır, G., Kibar, M., 2019. Muş İlinde Büyükbaş Süt Sığırcılığı İşletmelerinde Kullanılan Yem Çeşitleri ve Besleme Özellikleri. International Journal of Agricultural and Natural Sciences, 1(1): 61-68.

Bayraktar, H., Uğurlu, N., Yılmaz, A. M., 2010. Bitlis İli Ahlat ve Adilcevaz İlçeleri Süt Sığırı İşletmelerinde Barınakların Değerlendirmesi. Selçuk Tarım Gıda Bilim Dergisi, 24 (2):17-22.

Bogdanovic, V., Dedovic, R., Perisic, P., Stanojevic, D., Petrovic, M.D., Trivunovic, S., Kucevic, D., Petrovic, M. M., 2012. An Assessment of Dairy Farm Structure and Characteristics of Dairy Production Systems in Serbia. Biotechnology in Animal Husbandry, 28(4):689-696.

Boyar, S., Yumak, H., 2000. Isparta ve Burdur İlleri Süt Sığırcılığı İşletmelerinde Kaba ve Karma Yem Mekanizasyon Düzeyi, Karşılaşılan Sorunlar ve Çözüm Önerileri. YYÜZF Tarım Bilimleri Dergisi 10(1):11-18. 
Çapadağ, M., 2017. Erzurum İli Yakutiye İlçesi Büyükbaş Hayvancılık İşletmelerinin Yapısal Özellikleri. Yüksek Lisans Tezi. Atatürk Üniversitesi, Fen Bilimleri Enstitüsü.

Daş, A., İnci, H., Karakaya, E., Şengül, A.Y., 2014. Bingöl İli Damızlık Sığır Yetiştiricileri Birliğine Bağlı Sığırcılık İşletmelerinin Mevcut Durumu. TTDB Türk Tarım ve Doğa Bilimleri Dergisi, 1(3):421-429.

Demir, P., Aksu Elmalı, D., Işık, S., Tazegül, R., Ayvazoğlu, C., 2013. Kars İli Süt Sığırcılık İşletmelerinde Yem Kullanımı ve Hayvan Besleme Alışkanlıklarının Ekonomik Önemi. Atatürk Üniversitesi Veteriner Bilimleri Dergisi, 8(3):229-236.

Diler, A., Koçyiğit, R., Yanar, M., Aydın, R., Güler, O., Avcı, M., 2016. Erzurum İli Hınıs İlçesi Sığırcılık İşletmelerinde Sığır Besleme Uygulamaları Üzerine Bir Araştırma. Anadolu Tarım Bilimleri Dergisi, 31(1):149-156.

Diler, A., Koçyiğit, R., Yanar, M., Aydın, R., Güler, O., 2018. Erzurum İli Narman İlçesi Sığır Yetiştiricilerinin Sı̆̆ır Besleme Tercihleri. Iğdır Üniversitesi Fen Bilimleri Enstitüsü Dergisi, 8(1):341-349.

Dou Z, Galligan D. T., Ramberg J. C. F., Meadows, C., Ferguson, J. D., 2001. A Survey of Dairy Farming in Pennsylvania: Nutrient Management Practices and Implications. Journal of Dairy Science, 84(4):966-973.

Elmaz, Ö., Saatcı, M., Özçelik Metin, M., Sipahi, C., 2010. Burdur İli Süt Sığırcılı̆̆ı ve Özellikleri. Mehmet Akif Ersoy Üniversitesi Veteriner Fakültesi, Zootekni Anabilim Dali, Burdur. p.92.

Güler, O., Aydın, R., Yanar, M., Diler, A., Koçyiğit, R., Avcı, M., 2016. Erzurum İli Hınıs İlçesi Sı̆ğrcılık İşletmelerinin Sosyo-Ekonomik Yapısı. Alınteri Journal of Agriculture Science, 30 (1):, 27-37.

Igbang, S. K., Bekeh A. F., Ncha, O. S., 2021. Influence of Including Maize Offal in Diets on Growth, Carcass Composition and Economics of Clarias Gariepinus. GSC Biological and Pharmaceutical Sciences, 14(03):27-35.

Ildız, F., 1999. Tokat İli Merkez İlçesinde İthal Sı̆̆ır Yetiştiren Tarım İşletmelerinin Yapısı. Yüksek Lisans Tezi. Ankara Üniversitesi, Fen Bilimleri Enstitüsü.

Kaygısız, A., Tümer, R., Orhan, H., Vanlı, Y., 2008. Kahramanmaraş Bölgesi Süt Sığırcılığı İşletmelerinin Yapısal Özellikleri: I. Yetiştirme Uygulamaları. Süleyman Demirel Üniversitesi Ziraat Fakültesi Dergisi, 3(2):23-31.

Kaygısız, A., Tümer, R., 2009. Kahramanmaraş İli Süt Sı ğırcılığı İşletmelerinin Yapısal Özellikleri: 3. Hayvan Besleme Alışkanlıkları. KSÜ Doğa Bilimleri Dergisi, 12(1): 48-52.

Kırkpınar, F., Açıkgöz, Z., 2018. Feeding. In Animal Husbandry and Nutrition. Edited by Banu Yücel and Turgay Taşkın. Intechopen Co. London, UK.

Koçyiğit, R., Diler, A., Yanar, M., Güler, O., Aydın, R., Avcı, M., 2016. Süt Sığırcılığı İşletmelerinde Hayvan Sağlı̆̆ı, Veteriner Sağlık Hizmetleri ve Yetiştirici Memnuniyeti: Erzurum İli Hınıs İlçesi Örneği. Türk Tarım ve Doğa Bilimleri Dergisi, 3(1):24-32.

Kum, G., 2006. Antalya İli Holstein Irkı Damızlık Sığır Yetiştiricileri Birliğine Üye İşletmelerin Mevcut Durumu, Besleme Alışkanlıkları ve Sorunları. Yüksek Lisans Tezi. Yüzüncü Yıl Üniversitesi, Fen Bilimleri Enstitüsü. 
Lam, C., 2018. 2018 World Hunger and Poverty Facts and Statistics. http://www. worldhunger. org/world-hunger-and-poverty-facts-and-statistics/, Erişim Tarihi: 17.07.2021.

Sürmen, M., Yavuz, T., Çankaya, N., Töngel, M.Ö., 2008. Karadeniz Bölgesinde Hayvan Besleme Alışkanlıkları Üzerine Bir Araştırma. Tarım Bilimleri Araştırma Dergisi, 1(1):49-53.

Nyman, A.K., Emanuelson, U., Holtenius, K., Ingvartsen, K. L., Larsen, T., Waller, K. P., 2008. Metabolites and İmmunevariables Associated with Somatic Cell Counts of Primiparous Dairy Cows. Journal of Dairy Science, 91(8): 2996- 3009.

Okcu, M., 2020. Türkiye ve Doğu Anadolu Bölgesi Çayır-Mera Alanları, Hayvan Varlığı ve Yem Bitkileri Tarımının Mevcut Durumu. Atatürk Üniversitesi Ziraat Fakültesi Dergisi, 51(3):321-330.

Önal, A. R., Özder, M., 2008. Edirne İli Damızlık Sığır Yetiştiricileri Birliğine Üye İşletmelerin Yapısal Özellikleri. Tekirdağ Ziraat Fakültesi Dergisi, 5(2):197-203.

Özgür, E. M., 2017. Nüfus Dinamikleri, Çevre ve Sürdürülebilirlik. Coğrafi Bilimler Dergisi CBD, 15(1):1- 26.

Öztürk, O., Şen, C., Aydın, B., 2019. Hayvancılık İşletmelerinin Yem Bitkileri Yetiştiriciliği ve Mera Kullanım Alışkanlıklarının Karşılaştırmalı Analizi. Tarla Bitkileri Merkez Araştırma Enstitüsü Dergisi, 28(1): 29-38.

Savran, F., 2003. Çanakkale Damızlık Süt Sığırı Yetiştirici Birliğine Üye Olan ve Olmayan İşletmelerin Kullandıkları Üretim Teknikleri ve Sosyal Karakteristiklerinin Karşılaştırılması. Tarım Bilimleri Dergisi. 9(4):450-453.

Sezer. Y., Baytok, E., Akçay, A., 2020. Nevşehir İli Süt Sığırcılığı İşletmelerinin Yapısı ve Hayvan Besleme Uygulamaları Yönünden Değerlendirilmesi. Erciyes Üniversitesi Veteriner Fakültesi Dergisi, 17(3): 235-241.

Soyak, A., Soysal, M. İ., Gürcan, E. K., 2007. Tekirdağ İli Süt Sığırcılı̆̆ı İşletmelerinin Yapısal Özellikleri ve Bu İşletmelerin Siyah Alaca Süt Sığırlarının Çeşitli Morfolojik Özellikleri Üzerine Bir Araştırma. Tekirdağ Ziraat Fakültesi Dergisi, 4(3):297-305.

SPSS, 2013. IBM SPSS Statistics 21.0 for Windows. Armonk, NY.

Şahin, K., Yılmaz, İ. H., 2008. Van İlinde Yem Bitkileri Tarımı, Mera Kullanımı ve Sosyoekonomik Yapı Üzerine Bir Araştırma. Tarım Bilimleri Dergisi, 14(4):414-419.

Tatar, A. M., 2007. Ankara ve Aksaray Damızlık Sı ğır Yetiştiricileri İl Birliklerine Üye Süt Sığırcılığı İşletmelerinin Yapısı ve Sorunları. Doktora tezi. Ankara Üniversitesi, Fen Bilimleri Enstitüsü, Ankara.

Tilki, M., Sarı, M., Aydın, E., Işık, S., Aksoy, A. R., 2013. Kars İli Sığır İşletmelerinde Barınakların Mevcut Durumu ve Yetiştirici Talepleri: I. Mevcut Durum. Kafkas Universitesi Veteriner Fakültesi Dergisi, 19(1):109-116.

Tugay, A., Bakır, G., 2008. Giresun Yöresindeki Sığırcılık İşletmelerinde Kullanılan Yem Çeşitleri ve Hayvan Besleme Alışkanlıkları. Atatürk Üniversitesi Ziraat Fakültesi Dergisi, 39(2):231-239.

TUIK, 2019. Bitkisel ve Hayvansal Üretim İstatistikleri. T.C. Başbakanlık Türkiye İstatistik Kurumu. http://www.tuik.gov.tr Erişim Tarihi: 12.03.2021. 
Uçak, A., 1992. Samsun İlinde İthal İneklerle Çalışan İşletmelerin Durumu ve Sorunları Üzerine Bir Araştırma. Yüksek Lisans Tezi. Ankara Üniversitesi, Fen Bilimleri Enstitüsü.

Uzal, S., Uğurlu, N., 2006. Konya ili Besi Sığırı İşletmelerinin Yapısal Analizi. Selçuk Üniversitesi Ziraat Fakültesi Dergisi, 20(40):131-139.

Yeşi1, Z. 2015., Iğdır İli Damızlık Sığır Yetiştiricileri Birliğine Üye Merkez İlçe Tarım İşletmelerinin Mevcut Durumu ve Yapısal Özellikleri. Yüksek Lisans Tezi. Iğdır Üniversitesi, Fen Bilimleri Enstitüsü.

Yılmaz, İ., Kaylan, V., Yanar, M., 2020. Iğdır İli Büyükbaş Hayvan Yetiştiriciliğinin Yapısal Analizi. Journal of the Institute of Science and Technology. 10(1):684-693. 